\title{
MODEL EFEKTIVITAS ORGANISASI PEMERINTAH DESA
}

\author{
M. Irwan Tahir \\ Fakultas Politik Pemerintahan, Institut Pemerintahan Dalam Negeri \\ E-mail: irwan_thahir@yahoo.com
}

\begin{abstract}
ABSTRAK. Pencapaian tujuan Pemerintah Desa dalam penyelenggaraan pelayanan administratif belum efektif ditandai dengan adanya gejala kekurangpuasan masyarakat atas pelayanan administratif yang diselenggarakan oleh Pemerintah Desa. Berdasarkan fenomena tersebut maka disusun rumusan masalah penelitian yaitu mengapa Pemerintah Desa belum efektif dalam meyelenggarakan pelayanan administratif, dengan tujuan untuk menemukan faktor-faktor yang menentukan efektivitas Pemerintah Desa. Metode penelitian yang digunakan adalah metode kualitatif dengan pendekatan induktif dan strategi grounded research. Dalam metode penelitian kualitatif ini sumber data adalah para informan atau pihak yang memahami dan mengetahui permasalahan penelitian dengan metode Focused Group Discussion (FGD). Secara keseluruhan hasil penelitian menunjukkan bahwa penyelenggaraan pelayanan administratif belum tercapai dapat dilihat dari aspek kewenangan pengaturan dan pengurusan. Belum tercapainya tujuan tersebut berkaitan dengan beberapa faktor antara lain kepemimpinan, kewenangan, struktur organisasi, sumberdaya aparatur, keuangan, sarana dan prasarana, tatalaksana, serta budaya organisasi sebagai faktor internal, dan faktor kebijakan pemerintahan supradesa, pembinaan dan pengawasan, serta partisipasi masyarakat, sebagai faktor eksternal.
\end{abstract}

Kata kunci: Efektivitas Organisasi, Pemerintah Desa, Pelayanan Administratif.

\section{ORGANIZATIONAL EFFECTIVENESS MODEL OF VILLAGE GOVERNMENT}

ABSTRACT. Achievement of objectives in the village government has not been effective administrative service delivery is characterized by the symptoms of people who are not satisfied with the administrative services organized by the village government. Based on this phenomenon, the prepared formulation of research problems which is why the village government has not been effective in performing administrative services, with the aim to find the factors that determine the effectiveness of village government. The method used is qualitative method with an inductive approach and strategy grounded research. In this qualitative research methods data sources are informants or parties who understand and know the problems of research with the snowball method. Overall results showed that the implementation of administrative services has not been achieved can be seen from the aspect of setting up and maintenance of the authority. Not yet achieved these objectives with regard to several factors, among others, leadership, authority, organizational structure, personnel resources, finance, facilities and infrastructure, the management of, and organizational culture as internal factors, and factors upper government policies, guidance and supervision, as well as community participation, as external factors.

Key words: Organizational Effectiveness, Village Governance, Administrative Services.

\section{PENDAHULUAN}

Dalam penyelenggaraan pemerintahan desa, Pemerintah Desamerupakan penyelenggara pemerintahan desa bersama dengan Badan Permusyawaratan Desa. Pemerintah Desa pada dasarnya adalah organisasi pelayanan yang melaksanakan fungsi primer pelayanan kepada masyarakat (Wasistiono, 2006:23). Berkaitan dengan kondisi pelayanan publik di desa, Saragi (2004:140) berdasarkan hasil penelitiannya pada beberapa desa, antara lain Desa Sayang dan Desa Hegarmanah di Kecamatan Cikeruh, Kabupaten Sumedang, mengemukakan bahwa masyarakat kurang puas dengan kualitas pelayanan yang diberikan oleh Pemerintah Desa, kesenjangan terjadi dari segi waktu maupun tuntutantuntutan komplain lainnya yang diajukan oleh pemohon kepada Pemerintah Desa. Misalnya Pelayanan Kartu Penduduk (KTP) yang dirasakan sangat memakan waktu yang lama, pelayanan akta jual beli tanah yang dirasakan sangat berbelit-belit dan biayanya sangat mahal. Padahal menurut Nurcholis (2011:103), masyarakat desa sangat berkepentingan agar pemerintah desa menyediakan barang publik dan layanan publik, tentunya dengan biaya yang terjangkau dan prosedur yang mudah.

Pelayanan yang diberikan oleh organisasi pemerintahan, termasuk Pemerintah Desa, pada dasarnya berbeda dengan pelayanan yang diberikan oleh organisasi swasta atau pun organisasi kemasyarakatan secara khusus. Berkaitan dengan penyelenggaraan pelayanan publik yang diselenggarakan oleh Pemerintah Desa, wujud pelayanan yang diselenggarakan oleh organisasi pemerintah desa umumnya berupa pelayanan pemberian dokumen-dokumen pemerintahan yang dikeluarkan oleh Pemerintah Desa sesuai kewenangannya antara lain seperti perijinan, rekomendasi, surat keterangan dan pendataan. Sesuai dengan Undang Undang No. 25 Tahun 2009 tentang Pelayanan Publik, pelayanan-pelayanan tersebut disebut pelayanan administratif. Dengan demikian, pelayanan administratif oleh Pemerintah Desa adalah proses pemberian dokumen-dokumen pemerintahan yang dikeluarkan oleh Pemerintah Desa sesuai kewenangannya antara lain seperti perijinan, rekomendasi, surat keterangan dan pendataan. 
Kewenangan desa dalam menyelenggarakan pelayanan adminsitratif sesuai Permendagri No. 30 Tahun 2006 tentang Urusan Pemerintahan Kabupaten/ Kota yang Diserahkan kepada Desa, hasil rekapitulasi penulis menunjukkan terdapat 42 jenis pelayanan yang bersifat administratif yang diberikan oleh pemerintah desa, antara lain pelayanan administratif, misalnya pelayanan Surat Keterangan Hak Atas Tanah, pemberian Surat Keterangan pembuatan KTP, Rekomendasi pembuatan akta-akta kependudukan, perijinan IMB untuk bangunan sederhana di desa, dan sebagainya. Mengingat banyaknya jenis pelayanan administratif yang diselenggarakan oleh Pemerintah Desa tersebut, maka penulis memilih pelayanan pemberian Surat Keterangan Hak Atas Tanah oleh Pemerintah Desa sebagai obyek penelitian. Pertimbangannya adalah jenis layanan administratif ini sepenuhnya merupakan kewenangan desa dan relatif memiliki dampak pelayanan yang luas kepada masyarakat.

Berkaitan dengan pelayanan Surat Keterangan Hak Atas Tanah di Desa Cikeruh dan Desa Sukamantri, data yang ada menunjukkan bahwa intensitas pelayanan Surat Keterangan Hak Atas Tanah di Desa Cikeruh cenderung dua kali lipat jumlahnya dibandingkan frekwensi pelayanan di Desa Sukamantri. Hal ini dapat dimaklumi mengingat Desa Cikeruh berada di wilayah Jatinangor sebagai wilayah pengembangan dan pembangunan Bandung Timur, dimana transaksi peralihan hak atas tanah cukup tinggi seiring dengan pertumbuhan ekonomi di wilayah ini.

Namun demikian semakin tingginya kebutuhan pelayanan adminsitratif atas status hak atas tanahnya tersebut, ternyata tidak diikuti dengan dengan kepuasan pelayanan yang diterima oleh masyarakat sebagai tujuan yang ingin diwujudkaan oleh Pemerintah Desa. Berhubungan dengan penyelenggaraan pelayanan Surat Keterangan Hak Atas Tanah sendiri pada 2 (dua) Desa lokasi penelitian menunjukkan masih banyaknya keluhan masyarakat terkait dengan prosedur yang kurang jelas, lamanya waktu pelayanan, adanya beban biaya tambahan, serta kurangnya dukungan sarana dan prasarana dalam pemberian layanan tersebut, sebagaimana dapat dilihat pada tabel 1 .

Di samping itu gejala lain yang menunjukkan masih kurang efektifnya organisasi pemerintah desa dalam penyelenggaraan Surat Keterangan Hak Atas Tanah adalah masih buruknya pengelolaan administrasi desa serta rendahnya kompetensi perangkat desa dalam pelayanan adminsitratif kepada masyarakat desa. Bukubuku administrasi yang terkait dengan pencatatan kegiatan pelayanan administratif termasuk pelayanan surat keterangan hak atas tanah belum diadministrasikan dengan baik, ditambah lagi masih banyaknya perangkat desa yang belum memahami pentingnya pencatatan kegiatan administrasi. Fakta-fakta ini menunjukkan masih rendahnya kualitas pelayanan administratif yang diberikan oleh pemerintah desa, yang berarti pula bahwa belum efektifnya organisasi pemerintah desa dalam pencapaian tujuan organisasinya. Dengan demikian tujuan penelitian ini adalah untuk menemukan dan menganalisis faktor-faktor yang menyebabkan organisasi pemerintah desa belum efektif dalam menyelenggarakan pelayanan administratif kepada masyarakat.

Tabel 1. Keluhan terkait pelayanan Surat Keterangan Hak Atas Tanah Di Desa Cikeruh dan Desa Tanjungkerta

\begin{tabular}{|c|c|c|c|c|c|c|}
\hline \multirow{2}{*}{ No } & \multirow{2}{*}{$\begin{array}{l}\text { Jenis } \\
\text { Keluhan }\end{array}$} & \multicolumn{2}{|c|}{$\begin{array}{c}\text { Desa } \\
\text { Cikeruh }\end{array}$} & \multicolumn{2}{|c|}{$\begin{array}{c}\text { Desa } \\
\text { Tanjungkerta }\end{array}$} & \multirow{2}{*}{$\begin{array}{l}\text { Jumlah } \\
\text { Keluhan }\end{array}$} \\
\hline & & $F$ & $\%$ & $\mathrm{f}$ & $\%$ & \\
\hline 1 & $\begin{array}{l}\text { Prosedur } \\
\text { yang kurang } \\
\text { jelas }\end{array}$ & 7 & $35 \%$ & 13 & $65 \%$ & 20 \\
\hline 2 & $\begin{array}{l}\text { Keramahan } \\
\text { perangkat } \\
\text { desa dalam } \\
\text { pelayanan }\end{array}$ & 6 & $40 \%$ & 9 & $60 \%$ & 15 \\
\hline 3 & $\begin{array}{l}\text { Biaya } \\
\text { pelayanan }\end{array}$ & 3 & $33 \%$ & 6 & $73 \%$ & 9 \\
\hline 4 & $\begin{array}{l}\text { Waktu } \\
\text { pelayanan }\end{array}$ & 3 & $43 \%$ & 4 & $57 \%$ & 7 \\
\hline 5 & $\begin{array}{l}\text { Lain-lain } \\
\text { keluhan }\end{array}$ & 5 & $50 \%$ & 5 & $50 \%$ & 10 \\
\hline \multicolumn{2}{|c|}{ Total keluhan } & 29 & $23 \%$ & 98 & $77 \%$ & 61 \\
\hline
\end{tabular}

\section{METODE}

Dalam penelitian ini yang dijadikan obyek penelitian adalah Pemerintah Desa. Pemerintah Desa merupakan organisasi yang dibentuk secara formal untuk menyelenggarakan kewenangan untuk mengatur dan mengurus kepentingan masyarakat desa. Susunan organisasi dari Pemerintah Desa terdiri dari Kepala Desa (atau yang disebut dengan nama lain) dan perangkat desa (atau yang disebut dengan nama lain). Penelitian dilakukan menggunakan pendekatan kualitatif melalui pengamatan fenomena, yaitu adanya faktor-faktor yang mempengaruhi efektivitas organisasi pemerintah desa serta masih rendahnya pelayanan publik yang diterima oleh masyarakat desa sebagai akibat kurang efektifnya organisasi pemerintah desa. Kedua gejala atau fenomena inilah yang menjadi fokus amatan dan sasaran kajian penelitian ini. Tujuan akhirnya adalah menyusun model efektivitas pemerintah desa.

Alasan penelilti menggunakan pendekatan kualitatif dengan maksud untuk mencari makna dan upaya memahami proses dari keefektifan organisasi pemerintah desa dalam melaksanakan salah satu fungsi pokoknya yaitu penyelenggaraan pelayanan publik, secara spesifik pelayanan administratif kepada masyarakat. Hal tersebut sesuai pendapat Creswell (2012:352) yang menyatakan bahwa penelitian kualitatif adalah sebuah alat untuk memaparkan dan memahami makna yang berasal dari individu dan kelompok mengenai masalah sosial atau masalah individu.

Adapun strategi penelitian yang digunakan adalah "grounded theory", yaitu strategi penelitian yang di dalamnya Peneliti menghasilkan teori umum (generalisasi dari suatu proses, aksi atau nteraksi tertentu 
yang berasal dari pandangan-pandangan partisipan (Creswell, 2012:20). Dengan strategi penelitian ini Peneliti mengeksplorasi dan menemukan faktor-faktor yang menyebabkan organisasi pemerintah desa belum efektif dalam proses penyelenggaraan pelayanan publik, khususnya pelayanan administratif kepada masyarakat desa berupa pelayanan Surat Keterangan Hak Atas Tanah, yaitu proses pemberian surat keterangan dari Kepala Desa berupa pernyataan dari Kepala Desa menguatkan pernyataan kepemilikan hak atas tanah dari seseorang yang berdomisili dalam wilayah desanya. Selanjutnya peneliti merumuskan model efektivitas Pemerintah Desa sebagai generalisasi dari hasil penelitian.

\section{HASIL DAN PEMBAHASAN}

Secara keseluruhan hasil penelitian lapangan berkaitan dengan faktor-faktor yang berpengaruh terhadap efektivitas Pemerintah Desa dalam penyelenggaraan pelayanan administratif menunjukkan beberapa hal, yaitu pertama, kepemimpinan Kepala Desa di Desa Cikeruh yang kurang memiliki visi dalam penyelenggaraan pelayanan administratif, dalam hal ini pelayanan pemberian Surat Keterangan Hak Atas Tanah, berdampak pada kurang efektifnya pencapaian tujuan organisasi untuk meningkatkan pelayanan kepada masyarakat. Sedangkan di Desa Sukamantri dipengaruhi oleh faktor kepemimpinan dalam pengambilan keputusan oleh Kepala Desa. Eratnya keterkaitan antara kepemimpinan dengan efektivitas organisasi selain dikemukakan oleh Steers (1985:214), juga dikemukakan oleh Weisbord yang dikenal dengan model 6 (enam) kotak Weisbord (Thoha, 2000:98).

Kedua, kewenangan untuk menyelenggarakan pelayanan Surat Keterangan Hak Atas Tanah tidak diikuti oleh pengaturan dalam bentuk produk hukum di tingkat kabupaten maupun di tingkat desa lokasi penelitian. Hal ini berdampak tidak adanya landasan hukum dan pedoman untuk menyelenggarakan pelayanan administratif sehingga pencapaian tujuan organisasi tidak efektif. Hal ini sejalan dengan pendapat Hardjito (1997:65) yang mengemukakan bahwa salah satu komponen yang menentukan keberhasilan organisasi mencapai tujuannya adalah kewenangan (authority).

Ketiga, faktor struktur organisasi yang kurang mengakomodasi tugas-tugas pelayanan administratif pada kedua desa lokasi penelitian memberikan pengaruh kurang fokusnya Pemerintah Desa Cikeruh maupun Desa Sukamantri dalam pemberian pelayanan Surat Keterangan Hak Atas Tanah, berdampak pada pencapaian tujuan organisasi. Hal ini sejalan dengan pendapat McKinsey (Raisel, 1998:5) yang mengemukakan bahwa salah satu pilar yang menentukan kokohnya organisasi adalah struktur organisasi (organizational structure), yang merupakan cerminan dari shared values organisasi dalam upaya pencapaian sasaran dan tujuan organisasi secara optimal.

Keempat, tidak adanya analisis kebutuhan pegawai serta analisis jabatan untuk menentukan jenis jabatan dan jumlah personil di lingkungan Pemerintah Desa pada kedua lokasi penelitian memberikan pengaruh kurang maksimalnya pelayanan terhadap masyarakat dalam proses pemberian Surat Keterangan Hak Atas Tanah. Selain itu kompetensi perangkat desa yang rendah dikarenakan perangkat desa umumnya di lokasi penelitian tidak memperoleh pendidikan dan pelatihan yang sistematis dan berkesinambungan untuk meningkatkan kemampuan mereka. Diperparah lagi dengan rendahnya pemberian motivasi kepada para perangkat desa berupa tunjangan penghasilan yang kurang memadai untuk melaksanakan tugas-tugas pelayanan. Hal ini tentunya berdampak langsung terhadap efektivitas penyelenggaraan pelayanan administratif di desa lokasi penelitian. Indrawijaya (2000:20) mengemukakan bahwa "bagaimanapun baiknya organisasi lengkap sarana dan fasilitas kerja, semuanya tidak akan mempunyai arti tanpa ada manusia yang mengatur, menggunakan dan memeliharanya".

Kelima, kondisi di dua lokasi penelitian menunjukkan bahwa alokasi anggaran sangat terbatas untuk penyelenggaraan pelayanan administratif sebagai akibat tidak diprioritaskannya tugas-tugas pelayanan administratif sebagai tujuan yang harus dicapai oleh Pemerintah Desa. Anggaran yang terbatas berdampak secara langsung terhadap faktor lain utamanya dalam hal penyediaan sarana dan prasarana pelayanan serta mendukung kinerja sumberdaya aparatur yang ada. Keenam, ketersediaan sarana dan prasarana termasuk penggunaan teknologi komputer yang lebih memadai dalam mendukung tugas pelayanan di Desa Cikeruh cukup memberikan dampak positif bagi kepuasan masyarakat sebagai tujuan dalam penyelenggaranaan pelayanan administratif, meskipun dalam beberapa hal masih perlu ditingkatkan. Namun hal ini harus menjadi perhatian serius bagi Pemerintah Desa Sukamantri ke depan agar lebih membenahi sarana dan prasarana pelayanan yang ada di kantor desa, diharapkan nantinya pelayanan yang diharapkan oleh masyarakat dapat menjadi lebih baik. Padahal menurut Mariana (2006:243) profesionalisme birokrasi menyangkut kemampuan yang dihubungkan dengan tingkat kemajuan ilmu pengetahuan dan teknologi, dalam arti kata kemamuan untuk menggunakan fasilitas teknologi modern. Dengan penguasaan dalam menggunakan fasilitas teknologi modern, kelemahan negatif berupa lambatnya proses kerja birokrasi dapat teratasi.

Ketujuh, mekanisme kerja dalam pemberian pelayanan adminisitaratif yang kurang jelas dan kurang transparan oleh Pemerintah Desa kepada masyarakat pada 2 (dua) lokasi penelitian telah berdampak pada kurangnya kepuasan masyarakat dalam pelayanan Surat Keterangan Hak Atas Tanah. Selain itu tata laksana pelayanan yang tidak baku juga memberikan ketidak pastian pelaksanaan tugas bagi aparat pelaksana pelayanan. Hal ini juga sejalan pendapat Weisbord dengan konsep 6 (enam) kotak Weisbord (Thoha, 2000:98) yang mengemukakan bahwa mekanisme dan tata kerja mempengaruhi keberhasilan 
dan kestabilan organisasi.

Kedelapan, budaya organisasi yang dianut oleh Pemerintah Desa Cikeruh dan Desa Sukamantri bersandar pada nilai-nilai budaya masyarakat Sumedang yang telah ada sejak dahulu, dan saat ini telah diformalisasi melalui Perbup No. 113 Tahun 2009 tentang Sumedang Puseur Budaya Sunda. Namun demikian kesadaran dari para perangkat desa untuk mengaplikasikan nilai-nilai tersebut dalam pelaksanaan tugas-tugas pelayanan masih rendah. Hal ini juga sejalan dengan pendapat McKinsey (Raisel, 1998:5) dan Gibson (1997:14) yang mengemukakan bahwa salah satu kompnen yang mempengaruhi keberhasilan mencapai tujuannya adalah budaya organisasi (cultures).

Kesembilan, kebijakan pemerintahan supradesa khususnya dari Pemerintah Kabupaten Sumedang sampai saat ini belum ada kebijakan yang secara khusus berkaitan dengan dengan penyelenggaraan pelayanan administratif, baik dalam bentuk Perda mapun Perbup. Padahal agar pelayanan administratif yang diselenggarakan oleh pemerintah desa dapat diselenggarakan secara efektif, harus dilandaskan pada kebijakan yang dikeluarkan oleh pemerintah sebagai dasar hukum untuk mencegah kemungkinan timbulnya penyimpangan dalam pelaksanaannya. Menurut Rusli (2013:iv) kebijakan pulik dan pelayanan publik merupakan dua variabel penting dalam administrasi publik kontemporer yang memiliki hubungan kausalitas yang tinggi, tidak dapat dipisahkan walaupun bisa dibedakan fungsinya.

Kesepuluh, sampai saat ini Pemerintah Kabupaten Sumedang belum pernah melakukan pembinaan dan pengawasan berupa pemberian sanksi bagi Pemerintah Desa yang lalai dalam memberikan pelayanan administratif kepada masyarakat desa. Adapun pembinaan dan pengawasan yang dilakukan oleh pihak Kecamatan Jatinangor maupun Kecamatan Tanjungkerta hanya sebatas memfasilitasi penyelenggaraan pelayanan Surat Keterangan Hak Atas Tanah yang dilakukan oleh Pemerintah Desa. Adapun pengawasan dari BPD (Badan Permusyawaratan Desa) terkendala dengan kinerja anggotanya yang masih rendah, baik di Desa Cikeruh maupun Desa Sukamantri. Sedangkan LSM yang ada karena bebeberapa keterbatasan juga belum secara maksimal melakukan pembinaan dan pengawasan terhadap penyelenggaraan pelayanan administratif di Desa Cikeruh dan desa Sukamantri.

Yang terakhir kesebelas, kondisi di lapangan memperlihatkan bahwa partisipasi aktif dari masyarakat di Desa Cikeruh memberi tekanan terhadap Pemerintah Desa untuk mencapai tujuan dalam penyelenggaraan pelayanan administratif kepada masyarakat. Namun kurang tanggapnya Pemerintah Desa Cikeruh terhadap partisipasi masyarakat dalam bentuk suara, akses dan pengawasan berdampak pada kurang efektifnya pelayanan yang diberikan oleh Pemerintah Desa. Sebaliknya terjadi di Desa Sukamantri masyarakat kurang aktif dalam menyampaikan suara, mengakses atau menggunakan fungsi pengawasannya terhadap Pemerintah Desa, maka berdampak pada pencapaian tujuan pelayanan administratif menjadi tidak efektif.

Sebagaimana dijelaskan sebelumnya bahwa Pemerintah Desa sebagai organisasi adalah sebuah sistem, dan Pemerintahan pada semua tingkatan pada dasarnya adalah sebuah sistem. Sistem sendiri merupakan himpunan dari komponen yang tersusun sedemikian rupa sehingga merupakan satu kesatuan yang bulat dan utuh. Diantara komponen-komponen terdapat hubungan fungsional untuk mencapai suatu tujuan tertentu.

Organisasi sebagai sistem memiliki batas-batas sistem yang bersinggungan dengan lingkungan. Menurut Winardi (1997:159) organisasi dan lingkungannya memiliki batas sistem yang bersifat "poreus" (isitilah biologi: mampu ditembus oleh air). Dengan ciri ini organisasi disebut sebagai sistem terbuka, yaitu sistem yang selalu berhubungan dengan lingkungannya, yang pada tingkat tertentu organisasi dan lingkungannya tersebut membentuk ekosistem organisatoris atau organisasi yang lebih besar. Dalam memahami persoalan efektivitas Pemerintah Desa melalui pendekatan sistem, maka faktor-faktor yang menjadi penyebab bisa berasal dari dalam (internal) atau pun dari luar (eksternal) sistem organisasi dari Pemerintah Desa. Sesuai temuan penelitian bahwa faktor-faktor internal terdiri dari kepemimpinan, kewenangan, struktur organisasi, sumberdaya aparatur, keuangan, sarana praasarana, ketatalaksanaan dan budaya organisasi. Sedangkan faktor ekternal meliputi kebijakan supradesa, pembinaan dan pengawasan, serta partisipasi masyarakat. Faktorfaktor tersebut, baik internal maupun eksternal, berinteraksi satu sama lain dalam lingkungan organisasi bertujuan untuk menciptakan efektivitas Pemerintah Desa. Pemerintah Desa yang efektif diharapkan dapat meningkatkan kualitas pelayanan administratif kepada masyarakat, pada akhirnya memberikan kepuasan kepada masyarakat atas layanan yang diberikan.

Keterkaitan antara faktor-faktor yang mempengaruhi efektivitas Pemerintah Desa, secara skematik model efektivitas Pemerintah Desa dideskripsikan sebagaimana gambar 1 .

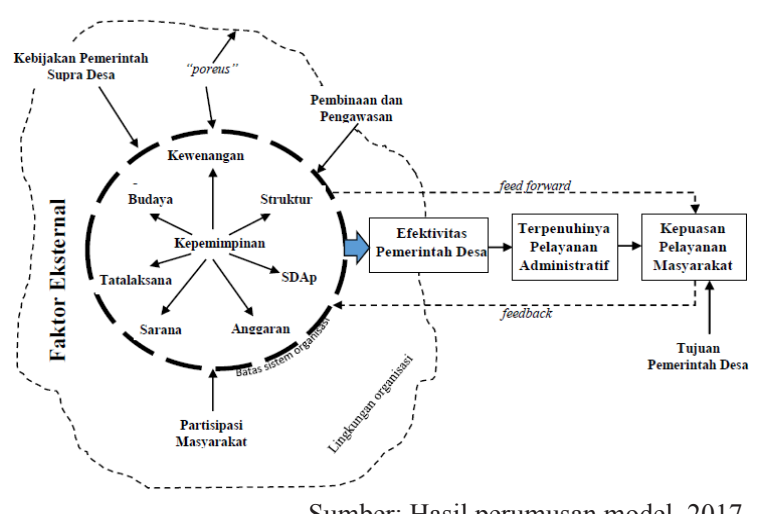

Sumber: Hasil perumusan model, 2017.

Gambar 1. Model Deskriptif Efektivitas Pemerintah Desa Dalam Penyelenggaraan Pelayanan Administratif 


\section{SIMPULAN}

Berdasarkan hasil penelitian dan analisis efektivitas Pemerintah Desa dalam penyelenggaraan pelayanan administratif diperoleh simpulan bahwa pelayanan Surat Keterangan Hak Atas Tanah sebagai salah satu jenis pelayanan administratif yang menjadi kewenangan desa menunjukkan bahwa penyelenggaraan pelayanan tersebut belum tercapainya tujuan organisasi dari Pemerintah Desa yaitu untuk meningkatkan kualitas pelayanan kepada masyarakat.

Kondisi tersebut di atas dipengaruhi oleh beberapa faktor, baik yang berada di dalam organisasi (internal) maupun dari luar organisasi (eksternal). Faktor internal dipengaruhi oleh kepemimpinan, kewenangan, struktur organisasi, sumberdaya aparatur, keuangan, sarana dan prasarana, tatalaksana serta budaya organisasi. Adapun faktor eksternal dipengaruhi oleh kebijakan dari pemerintahan supradesa, pembinaan dan pengawasan, serta partisipasi masyarakat. Faktor-faktor tersebut kemudian dirumuskan dalam sebuah model yang menggambarkan keterkaitan antara faktor-faktor dengan tujuan organisasi dari Pemerintah Desa dalam penyelenggaraan pelayanan administratif.

Berdasarkan simpulan tesebut, maka selanjutnya disusun model efektivitas organisasi untuk pemerintah desa dalam bentuk model skematik. Secara sederhana model skematik efektivitas organisasi Pemerintah Desa menjelaskan bahwa sejauhmana pencapaian tujuan Pemerintah Desa dipengaruhi oleh faktor internal dan faktor eksternal organisasi. Pemerintah Desa sebagai organisasi pelayanan untuk mencapai tujuan organisasinya dalam penyelenggaraan pelayanan administratif harus memperhatikan faktor-faktor yang berasal dari dalam organisasi seperti faktor kepemimpinan, kewenangan, struktur organisasi, sumberdaya aparatur, keuangan, sarana prasarana, ketatalaksanaan dan budaya organisasi, serta faktor-faktor dari luar organisasi meliputi kebijakan supradesa, pembinaan dan pengawasan, serta partisipasi masyarakat.

\section{DAFTAR PUSTAKA}

Creswell, J.W. (2012). Research Design - Pendekatan Kaulitatif, Kuantitatif dan Mixed (terjemahan: Achmad Fawaid), Yogyakarta: Pustaka Pelajar.
Gibson, J.L., Ivancevich, J.M., Donnelly, and James H. (1973). Organizations - Behavior Structure and Process, Richard D. Irwin Inc., Homewood, Illinois.

Hardjito, D. (1997). Teori Organisasi dan Teknik Pengorganisasian. Jakarta: Raja Grafindo

Indrawijaya, A.I. (2000). Perubahan dan Pengembangan Organisasi. Bandung: Sinar Baru.

Mariana, D. (2006), Reformasi Birokrasi Pasca Orde Baru, Sosiohumaniora Vol. 8, Bandung: Unpad.

Nurcholis, H. (2011). Pertumbuhan dan Penyelenggaraan Pemerintahan Desa. Jakarta: Erlangga.

Permendagri No. 30 Tahun 2006 tentang Urusan Pemerintahan Kabupaten/ Kota yang Diserahkan kepada Desa

Raisel, E.M. (1998), Mc Kinsey Way: Using The Technique of The World's Top Strategic Consultants to Help You And Your Business, New York: Mc Graw Hill.

Rusli, B. (2013). Kebijakan Publik Membangun Pelayanan Publik Yang Responsif, Bandung: Hakim Publishing.

Saragi, T.P. (2004). Mewujudkan Otonomi Masyarakat Desa - Alternatif Pemberdayaan Desa. Jakarta: CV. Cipruy.

Steers, R.M. (1985). Efektivitas Organisasi, Jakarta: Erlangga.

Thoha, M. (2000). Perilaku Organisasi-Konsep Dasar dan Aplikasinya. Jakarta: PT. Raja Grafindo.

Undang Undang No. 25 Tahun 2009 tentang Pelayanan Publik

Wasistiono, S dan Tahir, M.I. (2006). Prospek Pengembangan Desa, Bandung: Fokusmedia.

Winardi, J. 1997. Teori Organisasi dan Pengorganisasian. Jakarta: Rajawali Pers. 